\title{
Weight Estimation of Empty Carcass and Carcass Cuts of Female SenSi-1 Agrinak Chicken
}

\author{
Hidayat C, Iskandar S \\ Indonesian Research Institue of Animal Production \\ E-mail: maijonpurba@gmail.com \\ (received 03-02-2017; revised 04-03-2017; accepted 15-03-2017)
}

\begin{abstract}
ABSTRAK
Hidayat C, Iskandar S. 2017. Estimasi berat karkas dan potongan karkas ayam SenSi-1 Agrinak betina. JITV 22(1): 24-29. DOI: http://dx.doi.org/10.14334/jitv.v22i1.1626

Ayam SenSi-1 Agrinak adalah ayam lokal Sentul yang telah diseleksi untuk pertumbuhan selama enam generasi. Tujuan dari penelitian ini adalah untuk menghitung bobot karkas dan potongan karkas ayam SenSi-1 Agrinak betina berdasarkan data umur dan bobot hidup. membangun model matematik untuk menduga bobot karkas kosong dan potongan karkas ayam SenSi-1 Agrinak betina tanpa harus dilakukan proses pemotongan. Sebanyak 128 ekor ayam SenSi-1 Agrinak betina diambil secara acak dari populasi pengamatan, kemudian dipotong secara Islami pada umur 5, 8 dan 15 minggu, untuk diamati bagian karkasnya. Data dianalisis menggunakan metode analisis korelasi dan regresi. Hasil percobaan menunjukkan bahwa bobot hidup ayam SenSi-1 Agrinak betina memiliki korelasi positif tinggi dengan bobot karkas kosong dan potongan karkas ayam umur 5, 8 dan 15 minggu. Pendugaan bobot hidup, karkas, potongan karkas, rempela, hati dan lemak abdominal dengan menggunakan model matematik, menunjukan perbedaan yang rendah $(0,09 \%-4.43 \%)$ dari bobot aktual hasil pengukuran. Disimpulkan bahwa pada ayam SenSi-1 Agrinak betina bobot karkas dan potongan karkas dapat dihitung dengan menggunakan data umur (hari) dan bobot hidup (g) tanpa harus melakukan penyembelihan.
\end{abstract}

Kata Kunci: Ayam SenSi-1 Agrinak Betina, Karkas, Potongan Karkas

\section{ABSTRACT}

Hidayat C, Iskandar S. 2017. Weight estimation of empty carcass and carcass cuts of female SenSi-1 Agrinak chicken. JITV 22(1): 24-29. DOI: http://dx.doi.org/10.14334/jitv.v22i1.1626

SenSi-1 Agrinak chicken is Indonesian local chicken that was selected for growth rate for six generations. The aim of this study was to estimate of carcass weight and carcass cuts of female SenSi-1 Agrinak chicken, based on age and live weight. The chicks were reared intensively in colony wire cages and they were slaughtered with Islamic method when they reached age of 5, 8 and 15 weeks. Empty carcass and carcass cuts were weight in fresh. Data were analyzed using correlation and regression analysis method. Results showed that the live weight had a high positive correlation to carcass weight and carcass cuts weight of female SenSi-1 Agrinak chickens aged 5, 8 and 15 weeks. Estimation of live weight, carcass, carcass cuts, gizzard, liver and abdominal fat of female SenSi-1 Agrinak, using mathematical model, showed small value differences $(0.09-4.43 \%)$ from the actual data. It was concluded that female SenSi-1 Agrinak chicken's carcass weight and carcass cuts, could be estimated based on of age in days and live-body weight in gram without slaughtering.

Key Words: Female SenSi-1 Agrinak Chicken, Empty Carcass, Carcass Cuts

\section{INTRODUCTION}

Indonesian Research Institute for Animal Production (IRIAP) has carried out research on improving breeds of native chicken since 15 years ago. One of the improved breeds was SenSi-1 Agrinak, which was selected from native Sentul breed. SenSi-1 Agrinak was then released officially by Ministery of Agriculture of the Republic of Indonesia decree early in 2017. SenSi-1 Agrinak was the results of seletion of native Sentul chicken for 10 weeks growth rate and it was a candidate for one of local breed for male line incorporated in local chicken crossing program (Iskandar et al. 2012; Hasnelly et al. 2012; Iskandar \&
Sartika 2015). Sulandari et al. (2007) and Sartika \& Iskandar (2007) reported that native Sentul chicken was a dual purpose type chicken with having medium body size.

Although SenSi-1 Agrinak chicken has been introduced to Indonesian local chicken industry, continue examination on every aspect of economic value of the breed has to be carried out. Carcass quality is one aspect that has to be observed, as the breed is utilized for local chicken meat supply. Holcman et al. (2003) reported that economically, carcass quality was determined by the portion of empty carcass and carcass cuts preferred by the consumers. Empty carcass, breast part, thigh both upper and lower parts were important 
economically parts, determining quality marketed products. However, since invasive like slaughtering in order to gather data, has been little bit time consuming and disposing valuable selected chicken, estimation through noninvasive method, like mathematical method, is worth pursuing.

Furthermore, Khosravinia et al. (2006) indicated that the noninvasive methods provide an opportunity to collect slaughter value information from live birds for selection while still alive. The regression models can be used to predict carcass, breast and leg weights utilizing data on body conformation traits and weight at different ages. Raji et al. (2010) also suggested that since slaughter value parameters were difficult to obtain in the live animal except after slaughter, simple, reliable and indirect methods for the estimation was a necessity. The aim of this study was to estimate of weight of empty carcass and carcass cuts of female SenSi-1 Agrinak chicken based on age and live weight.

\section{MATERIALS AND METHODS}

A total of 128 of female SenSi-1 Agrinak chickens were taken from a population used in an massive nutritional experiment (Hidayat \& Iskandar 2017), which was applying intensive husbandry, where the chicks were kept in colony wire cages and fed rations, containing $17-20 \%$ crude protein with energy of 2800$3000 \mathrm{kcal} \mathrm{ME} / \mathrm{kg}$. When they reached age of 5, 8 and 15 weeks, they were randomly taken to be slaughtered according to Islamic slaughter method. Fresh empty carcass, carcass cuts (head, neck, wings, whole back, whole breast, upper and lower thighs, shanks), gizzard, liver and fat pad were then weighed.

Data were analyzed using correlation and regression analysis method. Mathematical model for estimating live body weight was using: $\mathrm{y}=\mathrm{a}+\mathrm{bx}$, where $\mathrm{y}$ was body live weight ( $\mathrm{g} / \mathrm{bird}$ ); $\mathrm{x}$ was age in days; a was constanta; and $b$ was the slope of the line. Whilst in estimating empty carcass and carcass cuts weight, data were subjected to regression equation of $y=a+b_{1} x_{1}+$ $\mathrm{b}_{2} \mathrm{X}_{2}$, where $\mathrm{y}$ was the estimated weight of empty carcass or carcass cuts (in $\mathrm{g} / \mathrm{bird}$ ); $\mathrm{x} 1$ was actual body live weight (g/bird); $\mathrm{x} 2$ was the age when the variable measured (days), b1 was the slope of the $\mathrm{x} 1$ line; and $\mathrm{b} 2$ was the slope of $\mathrm{x} 2$ line.

Data were subjected to ANOVA (analysis of variance) and correlation between two observed variables as suggested by Steel \& Torrie (1993). Multiple regression analysis for any change in the fixed variable (age and live weight), influenced unfixed variable (weight of empty carcass or carcass cuts), were analyzed using the SPSS statistical software (Levesque 2007). For the particular measurement such as percentage values, data were examined for normality before running with ANOVA.

\section{RESULTS AND DISCUSSIONS}

Live weight, empty carcass weight, and carcass cuts weight of the analyzed chicks at three different ages are presented in Table 1. As it was expected, that the increase in weight of all measured variables increased as the age increased, which indicated that they were in good keeping management.

Table 1. Average weight of empty carcass and carcass cuts

\begin{tabular}{lccc}
\hline $\begin{array}{l}\text { Variables } \\
(\mathrm{g} / \mathrm{bird})\end{array}$ & $\begin{array}{c}\text { Five } \\
\text { weeks of age }\end{array}$ & $\begin{array}{c}\text { Eight } \\
\text { weeks of age }\end{array}$ & $\begin{array}{c}\text { Fifteen } \\
\text { weeks of age }\end{array}$ \\
\hline Live weight & $237 \pm 10.3$ & $388 \pm 11.7$ & $1247 \pm 17.1$ \\
Empty carcass $^{1)}$ & $130 \pm 6.9$ & $221 \pm 7.7$ & $803 \pm 11.3$ \\
Head and neck & $25.0 \pm 0.8$ & $38.7 \pm 0.9$ & $103 \pm 1.6$ \\
Whole back & $34.2 \pm 1.7$ & $59.9 \pm 2.1$ & $201 \pm 3.4$ \\
Two wings & $22.1 \pm 1.1$ & $34.6 \pm 1.1$ & $109 \pm 1.7$ \\
Whole breast & $33.3 \pm 1.6$ & $53.6 \pm 2.1$ & $218 \pm 3.9$ \\
Two upper thighs & $21.4 \pm 1.0$ & $37.2 \pm 1.4$ & $144 \pm 2.3$ \\
Two lower thighs & $21.2 \pm 1.1$ & $35.9 \pm 1.3$ & $131 \pm 2.3$ \\
Two shanks & $12.1 \pm 0.5$ & $19.1 \pm 0.6$ & $50.0 \pm 1.0$ \\
Gizzard & $8.63 \pm 0.4$ & $12.4 \pm 0.4$ & $24.0 \pm 0.6$ \\
Liver & $6.55 \pm 0.3$ & $8.70 \pm 0.3$ & $23.1 \pm 0.5$ \\
Abdominal fat & $0.20 \pm 0.1$ & $2.54 \pm 0.5$ & $17.3 \pm 2.2$ \\
\hline
\end{tabular}

\footnotetext{
${ }^{1)}$ Empty carcass is the carcass without head, neck, legs, and oval
} 
Table 2. Analysis of variance on empty carcass and carcass cuts as the percentage of live-body weight of female SenSi-1 Agrinak chicken

\begin{tabular}{lccccccccccc}
\hline \hline $\begin{array}{l}\text { Age } \\
\text { (weeks) }\end{array}$ & $\begin{array}{l}\text { EC } \\
(\%)\end{array}$ & $\begin{array}{c}\text { HN } \\
(\%)\end{array}$ & $\begin{array}{c}\text { WB } \\
(\%)\end{array}$ & $\begin{array}{l}\text { TW } \\
(\%)\end{array}$ & $\begin{array}{c}\text { WBr } \\
(\%)\end{array}$ & $\begin{array}{c}\text { TUT } \\
(\%)\end{array}$ & $\begin{array}{c}\text { TLT } \\
(\%)\end{array}$ & $\begin{array}{c}\text { TS } \\
(\%)\end{array}$ & $\begin{array}{c}\text { G } \\
(\%)\end{array}$ & $\begin{array}{c}\text { L } \\
(\%)\end{array}$ & $\begin{array}{c}\text { AFP } \\
(\%)\end{array}$ \\
\hline 5 & $54.38^{\mathrm{b} 1)}$ & $10.70^{\mathrm{a}}$ & $14.37^{\mathrm{c}}$ & $9.32^{\mathrm{a}}$ & $14.01^{\mathrm{b}}$ & $9.00^{\mathrm{c}}$ & $8.86^{\mathrm{b}}$ & $5.13^{\mathrm{a}}$ & $3.68^{\mathrm{a}}$ & $2.77^{\mathrm{a}}$ & $0.08^{\mathrm{a}}$ \\
8 & $56.59^{\mathrm{b}}$ & $10.06^{\mathrm{b}}$ & $15.38^{\mathrm{b}}$ & $8.93^{\mathrm{b}}$ & $13.56^{\mathrm{b}}$ & $9.51^{\mathrm{b}}$ & $9.19^{\mathrm{b}}$ & $4.91^{\mathrm{b}}$ & $3.25^{\mathrm{b}}$ & $2.24^{\mathrm{b}}$ & $0.68^{\mathrm{a}}$ \\
15 & $64.50^{\mathrm{a}}$ & $8.24^{\mathrm{c}}$ & $16.16^{\mathrm{a}}$ & $8.72^{\mathrm{b}}$ & $17.48^{\mathrm{a}}$ & $11.59^{\mathrm{a}}$ & $10.54^{\mathrm{a}}$ & $4.02^{\mathrm{c}}$ & $1.90^{\mathrm{c}}$ & $1.83^{\mathrm{c}}$ & $1.33^{\mathrm{a}}$ \\
\hline SEM & 0.69 & 0.15 & 0.13 & 0.07 & 0.24 & 0.14 & 0.10 & 0.06 & 0.10 & 0.05 & 0.09 \\
\hline
\end{tabular}

1) Values in the same column with the same superscript are not significantly difference $(\mathrm{P}>0.05)$

EC = Empty carcass TLT = Two lower thighs

$\mathrm{HN}=$ Head and neck $\quad$ TS $=$ Two shanks

WB = Whole back $\quad \mathrm{G}$ = Gizzard

$\mathrm{TW}=$ Two wings $\quad \mathrm{L}=$ Liver

$\mathrm{WBr}=$ Whole breast $\quad$ AFP $=$ Abdominal fat pad

TUT $=$ Two upper thighs

As shown in Table 2, which was the result of statistical analysis (ANOVA) on the empty carcass and carcass cuts variables measured as the percentage of live weight of the same observed of the individual chicken, indicated that the simultaneous development of every carcass cut was not the same as the bird aging.

As seen in Table 2, percentage of empty carcass at the age of five and eight weeks was not significantly different $(\mathrm{P}>0.05)$, but it significantly increased $(\mathrm{P}<0.05)$ by the age of 15 weeks. The same trends were also showed by the other variables measured unless head and neck, two wings, two shanks, gizzard and liver, which were declining at the older age. The abdominal fat pad, which also increased at the age of 15 weeks $(\mathrm{P}>0.05)$, which was due to a large differences between individual of female chickens. The uneven acceleration of growth of organs as a proportion to body mass was also reported by Tickle et al. (2014), showing that the heart, lungs, and intestines decreased in size from hatch to slaughter weight when considered as a proportion of body mass.

\section{Correlation between two variables}

The correlation between two parameters measured of female SenSi-1 Agrinak chicken at the age of 5, 8 and 15 weeks is presented in Table 3. Body live weight of female SenSi-1 Agrinak chicken had considerable ( $r$ $=0.99-0.67$ ) relation with empty carcass and carcass cuts as an impact of growth status, which was at the prime status in their live to build the body mass as much as the genetic capacity and conducive environment. Rymkiewicz \& Bochno (1999) reported this closed relation in chicken, Kleczek et al. (2006) in duck and Vali et al. (2005) in quail. However, Raji et al. (2010) and Shafey et al. (2013) found out the correlation (r) varied from 0.98 to 0.26 in modern broiler chicken. The different might have been due to different in breed (Choo et al. 2014).

Therefore, body live weight is a good indicator that can be used to estimate empty carcass and carcass cuts weight of native chicken, although in this experiment, low correlation was shown in abdominal fat pad, as it was also reported by Guo et al. (2011) in $13^{\text {th }}$ generation of broiler chicken selected for divergent adipose tissue. However, it was in contrast with modern broiler chicken reported by Musa et al. (2006); Ojedapo et al. (2008).

\section{Linear regression}

The results of analysis by the linear regression are presented in Table 4. The coefficient determination were high $\left(\mathrm{R}^{2}=0.99-0.88\right)$ except for Abdominal fat pad was low (0.453), showing that the relationship between Y (estimated weight of empty carcass) with A (actual age of individual) and LW (actual live weight of an individual), were high except for abdominal fat pad.

The $\mathrm{R}^{2}$ is also known as coefficient of determination, measuring the goodness of fit of the mathematical model, giving value to unfixed variables proportionally to fixed variable. The value of $\mathrm{R}^{2}$ stands between 0 and 1 . The fit model has the $\mathrm{R}^{2}$ closed to value of 1 .

The models presented in Table 4 worked well in estimating the weight of carcass of live female SenSi-1 Agrinak chicken. This finding will certainly good information to genetic researchers in estimating how much carcass will be yielded by the selected chicken. Moreover, the information will be useful for the culinary in estimating how much they can obtained the carcass and carcass cuts of the female SenSi-1 Agrinak chicken in term of economic. Actually, such models had been reported on the different breed of chicken, which 
showed the good fit for every particular breed or species observed (Raji et al. 2010; Banerjee 2011; Shafey et al. 2013). The reported models, however, those vary for every breed and species lead to examine the models that reported in this research, to see how accurate the models that can be calculated for the actual value. The model were then examined, using the actual weight of female SenSi-1 Agrinak chicken at the age of 15 weeks.
The test results of the models are presented in Table 5 , showing that there were very little variation in gap between actual values and estimated values (0.09$4.43 \%)$. Therefore the mathematical models in estimating the carcass and carcass cuts of female SenSi1 Agrinak chicken could be applied covering the age of 5 to 15 weeks.

Table 3. Correlation between two measured variables of female SenSi-1 Agrinak chicken at the age of 5, 8 and 15 weeks

\begin{tabular}{|c|c|c|c|c|c|c|c|c|c|c|c|c|}
\hline Variables & $\begin{array}{c}\text { Body- } \\
\text { live } \\
\text { weight }\end{array}$ & $\begin{array}{c}\text { Empty } \\
\text { Carcass }\end{array}$ & $\begin{array}{c}\text { Head \& } \\
\text { neck }\end{array}$ & $\begin{array}{l}\text { Whole } \\
\text { back }\end{array}$ & $\begin{array}{c}\text { Two } \\
\text { wings }\end{array}$ & $\begin{array}{l}\text { Whole } \\
\text { breast }\end{array}$ & $\begin{array}{l}\text { Two } \\
\text { upper } \\
\text { thighs }\end{array}$ & $\begin{array}{l}\text { Two } \\
\text { lower } \\
\text { thighs }\end{array}$ & $\begin{array}{c}\text { Two } \\
\text { shanks }\end{array}$ & Gizzard & Liver & $\begin{array}{c}\text { Abdominal } \\
\text { fat pad }\end{array}$ \\
\hline Body-live weight & 1 & $0.997^{* * *}$ & $0.990^{* * *}$ & $0.994^{* * *}$ & $0.993^{* *}$ & $0.991^{* *}$ & $0.993^{* *}$ & $0.994^{* * *}$ & $0.984^{* *}$ & $0.930^{* *}$ & $0.974^{* *}$ & $0.701^{* *}$ \\
\hline Empty carcass & & 1 & $0.989^{* *}$ & $0.996^{* *}$ & $0.995^{* *}$ & $0.995^{* *}$ & $0.997^{* *}$ & $0.996^{* *}$ & $0.983^{* *}$ & $0.927^{* * *}$ & $0.970^{* *}$ & $0.698^{* * *}$ \\
\hline Head \& neck & & & 1 & $0.986^{* *}$ & $0.987^{* *}$ & $0.982^{* *}$ & $0.982^{* *}$ & $0.988^{* *}$ & $0.983^{* *}$ & $0.924^{* *}$ & $0.958^{* *}$ & $0.702^{* *}$ \\
\hline Whole back & & & & 1 & $0.989^{* * *}$ & $0.986^{* *}$ & $0.991^{* *}$ & $0.992^{* * *}$ & $0.980^{* * *}$ & $0.934^{* *}$ & $0.969^{* *}$ & $0.710^{* *}$ \\
\hline Two wings & & & & & 1 & $0.987^{* *}$ & $0.989^{* * *}$ & $0.995^{* *}$ & $0.988^{* *}$ & $0.924^{* *}$ & $0.969^{* *}$ & $0.678^{* *}$ \\
\hline Whole breast & & & & & & 1 & $0.993^{* *}$ & $0.986^{* *}$ & $0.973^{* *}$ & $0.912^{* *}$ & $0.959^{* *}$ & $0.682^{* *}$ \\
\hline Two upper thighs & & & & & & & 1 & $0.989^{* *}$ & $0.976^{* *}$ & $0.924^{* *}$ & $0.963^{* *}$ & $0.701^{* * *}$ \\
\hline Two lower thighs & & & & & & & & 1 & $0.984^{* *}$ & $0.924^{* *}$ & $0.972^{* *}$ & $0.699^{* *}$ \\
\hline Two shanks & & & & & & & & & 1 & $0.929^{* *}$ & $0.968^{* *}$ & $0.637^{* *}$ \\
\hline Gizzard & & & & & & & & & & 1 & $0.923^{* *}$ & $0.645^{* *}$ \\
\hline Liver & & & & & & & & & & & 1 & $0.686^{* *}$ \\
\hline Abdominal fat pad & & & & & & & & & & & & 1 \\
\hline
\end{tabular}

** Highly correlated $(\mathrm{P}<0.01)$

Table 4. Mathematical models of estimating live weight, empty carcass and carcass cuts of female SenSi-1 Agrinak chicken

\begin{tabular}{llc}
\hline \hline Variables(g/bird) & Mathematical models & Coeff.determination $\left(\mathrm{R}^{2}\right)$ \\
\hline Body live weight & $\mathrm{Y}=-139.87+12.70 \mathrm{~A}^{1)}$ & 0.947 \\
Empty carcass & $\mathrm{Y}=-45.22+0.485 \mathrm{~A}+0.638 \mathrm{LW}$ & 0.992 \\
Head \& neck & $\mathrm{Y}=3.14+0.198 \mathrm{~A}+0.063 \mathrm{LW}$ & 0.980 \\
Whole back & $\mathrm{Y}=-8.64+0.168 \mathrm{~A}+0.154 \mathrm{LW}$ & 0.986 \\
Two wings & $\mathrm{Y}=0.054+0.069 \mathrm{~A}+0,081 \mathrm{LW}$ & 0.983 \\
Whole breast & $\mathrm{Y}=-13.57-0.021 \mathrm{~A}+0.187 \mathrm{LW}$ & 0.980 \\
Two upper thighs & $\mathrm{Y}=-13.21+0.178 \mathrm{~A}+0.11 \mathrm{LW}$ & 0.984 \\
Two lower thighs & $\mathrm{Y}=-6.643+0.041 \mathrm{~A}+0.107 \mathrm{LW}$ & 0.984 \\
Two shanks & $\mathrm{Y}=3.43+0.018 \mathrm{~A}+0.036 \mathrm{LW}$ & 0.967 \\
Gizzard & $\mathrm{Y}=3.408+0.101 \mathrm{~A}+0.008 \mathrm{LW}$ & 0.886 \\
Liver & $\mathrm{Y}=3.24-0.030 \mathrm{~A}+0.018 \mathrm{LW}$ & 0.951 \\
Abdominal fat pad & $\mathrm{Y}=-4.38+0.026 \mathrm{~A}+0.015 \mathrm{LW}$ & 0.453 \\
\hline
\end{tabular}

${ }^{1)}$ It stands for age (day); LW stands for live weight (g/bird) 
Table 5. Actual versus estimated values of observed variables of female SenSi-1 Agrinak chicken

\begin{tabular}{lcccc}
\hline \hline \multirow{2}{*}{ Variables } & Actual & Estimated & \multicolumn{2}{c}{ Actual versus estimated values } \\
\cline { 4 - 5 } Body live weight & $(\mathrm{g})$ & $(\mathrm{g})$ & $(\mathrm{g})$ & 4.43 \\
Empty carcass & 1247 & 1193.63 & 52.93 & 0.26 \\
Head \& neck & 803 & 801.291 & 2.07 & 0.09 \\
Whole back & 103 & 102.491 & 0.09 & 0.17 \\
Two wings & 201 & 201.038 & 0.35 & 0.23 \\
Whole breast & 109 & 108.306 & 0.25 & 0.16 \\
Two upper thighs & 218 & 217.414 & 0.35 & 0.32 \\
Two lower thighs & 144 & 143.897 & 0.46 & 0.15 \\
Two shanks & 131 & 131.091 & 0.20 & 0.28 \\
Gizzard & 50 & 50.212 & -0.14 & 1.29 \\
Liver & 24 & 23.989 & -0.31 & 1.44 \\
Abdominal fat pad & 23 & 22.536 & 0.33 & 2.03 \\
\hline
\end{tabular}

\section{CONCLUSION}

In female SenSi-1 Agrinak chicken, estimation of weight of carcass and carcass cut can be calculated using the data of age (day) and live-body weight ( $\mathrm{g}$ ). The study also informed that estimation of body-live weight can be calculated based on the data of age (day). Furthermore, there is a high correlation relationship between the body-live weight with carcass cut.

\section{ACKNOWLEDGEMENT}

The authors would like to thank to technicians of the research chicken complex of the Indonesian Research Institute for Animal Production for support to this particular research.

\section{REFERENCES}

Banerjee S. 2011. Prediction of carcass cuts using some noninvasive predictors on broiler ducks reared in hot and humid climate of Eastern India. World Appl Sci J. 12:642-651.

Choo YK, Kwon HJ, Oh ST, et al. 2014. Comparison of Growth Performance, Carcass Characteristics and Meat Quality of Korean Local Chickens and Silky Fowl. Asian-Australasian J Anim Sci. 27:398-405.

Guo L, Sun B, Shang Z, Leng L, Wang W, Wang N, Li H. 2011. Comparison of adipose tissue cellularity in chicken lines selected divergently for fatness. Poult Sci. 90:2024-2034.

Hasnelly Z, Sartika T, Zainuddin D, Komaruddin. 2012. Persilangan pada ayam lokal (KUB, Sentul, Gaok) untuk meningkatkan produksi daging unggas nasional. Iskandar S, Resnawati H, Priyantini A, Sartika T, Damayanti R, editors. Prosiding Workshop Nasional Unggas Lokal. Bogor (Indones): Indonesian Center for Animal Research and Development. p. 102- 108.

Hidayat C, Iskandar S. 2017. Pengaruh Berbagai Kadar Protein dan Energi Ransum pada Pertumbuhan dan Nilai Ekonomis Ayam Sentul-G5 Betina, Puastuti W, Muharsini S, Inounu I, Tiesnamurti B, Kusumaningtyas E, Wina E, Herawati T, Hartati, Hutasoit R. Prosiding Seminar Nasional Teknologi Peternakan dan Veteriner. Bogor (Indones): Indonesian Center for Animal Research and Development. (Inpress) p.443-451.

Holcman A, Vadnjal R, Zlender B, Stibilj V. 2003. Chemical composition of chicken meat from free range and extensive indoor rearing. Arch Geflügelk. 67:120-124.

Iskandar S, Gunawan B, Resnawati H. 2012. Initiation of selection in Sentul native chicken: Ten weeks of growth rate. Proceedings International Conference on Livestock Production and Veterinary Technology. Indonesia Center for Animal Research and Development. p: 3539.

Iskandar S, Sartika T. 2015. Selection for 10 weeks old bodyweight on Sentul chicken. Budhi SPS, Bachruddin Z, Utomo R, Widodo, Suparno, Erwanto Y, Adiarto, Ismaya, Hartatik T, Wihandoyo, Baliarti E, Santosa AK, Nurtini S, Guntoro B, Dono DN, Zuprizal, Maharjan 
LK, Hansen OH, Yoshimura Y, Young A, Opatpatanakit Y. Proceedings of the $6^{\text {th }}$ ISTAP, International Seminar on Topical Animal Production. Yogyakarta (Indones): Universitas Gadjah Mada. p. 387-390.

Khosravinia H, Murphy NHN, Govindaiah MG. 2006. Imposing restriction in selection for disproportionate cut-up carcass yield in an experimental flock of broiler chicken. J Poultry Sci. 43:109-119.

Kleczek K, Wawro K, Wilkiewicz-Wawro E, Makowski W. 2006 Multiple regression equations to estimate the content of breast muscles, meat, and fat in muscovy ducks. Poult Sci. 85:1318-1326.

Levesque R. 2007. SPSS programming and data management: A guide for SPSS and SAS users. 4th ed. Chicago, Illinois (USA): SPSS Inc.

Musa H, Chen GH, Cheng JH, Li BC, Mekki DM. 2006. Study on carcass characteristics of chicken breeds raised under the intensive condition. Int J Poult Sci. 5:530-533.

Ojedapo LO, Akinokun O, Adedeji TA, Olayeni TB, Ameen SA, Amao SR. 2008. Effect of strain and sex on carcass characteristics of three commercial broilers reared in deep litter system in the derived savanna area of Nigeria. World J Agric Sci. 4:487-491.

Raji AO, Igwebuike JU, Kwari ID. 2010. Regression models for estimating breast, thigh and fat weight and yield of broilers from noninvasive body measurements. Agric Biol J N Am. 1:469-475.
Rymkiewicz J, Bochno R. 1999. Estimation of breast muscle weight in chickens on the basis of live measurements. Arch Geflugelkd. 63:229-233.

Sartika T, Iskandar S. 2007. Mengenal plasma nutfah ayam Indonesia dan pemanfaatannya. 1st ed. Bogor (Indones): Balai Penelitian Ternak.

Shafey TM, Olodan MA, Hussein EOS, Al-Batshan HA. 2013. The effect of sex on the accuracy of predicting carcass composition of Ross broiler chicken. J Anim Plant Sci. 23:975-980.

Steel RGD, Torrie JH. 1993. Prinsip dan prosedur statistika: suatu pendekatan biometrik. Jakarta (Indones): PT Gramedia Pustaka Utama.

Sulandari S, Zein MSA, Paryanti S, Sartika T, Sidadolog JHP, Astuti M, Widjastuti T, Sujana E, Darana S, Setiawan I, Garnida D, Iskandar S, Zainuddin D, Herwati T, Wibawan IWT. 2007. Keanekaragaman sumber hayati ayam lokal Indonesia: Manfaat dan potensi. Bogor (Indones): Pusat Penelitian Biologi LIPI.

Tickle PG, Paxton H, Rankin JW, Hutchinson JR, Codd JR. 2014. Anatomical and biomechanical traits of broiler chickens across ontogeny. Part I. Anatomy of the musculoskeletal respiratory apparatus and changes in organ size. Peer J. 432:1-17

Vali N, Edriss MA, Rahmani HR. 2005. Genetic parameters of Body and some carcass traits in two quail strains. Int J Poult Sci. 4:296-300. 